\title{
Intermediary IP injunctions in the EU and UK experiences: when less (harmonization) is more?*
}

by Eleonora Rosati ${ }^{* *}$

\section{Abstract}

This contribution provides an overview of EU and UK experiences, and focuses on certain threads that have emerged from relevant case law in the area of intermediary IP injunctions. Following a review of CJEU decisions, the article considers UK case law in the area of blocking injunctions. It discusses two key issues arisen from the experience of this Member State (the possible expansion of blocking injunctions to different areas and intermediaries, and the responsibility for the costs of injunctions), including whether - lacking an unambiguous legislative framework - the parallel evolution at the CJEU level may provide interpretative guidance. The principal conclusion is that, despite EU harmonization efforts in the area of IP enforcement, there are significant gaps in the resulting framework. This prompts the question (which is answered in the affirmative) whether, in the context of the EU Commission's Digital Single Market Strategy, the EU should merely reform the current enforcement framework or - together with this - also push the boundaries of harmonization further.

\footnotetext{
* This contribution is derived from my presentation during the $7^{\text {th }}$ GRUR Int/JIPLP Joint Seminar, which was held at the Humboldt University of Berlin on 14 November 2016.

** Lecturer in Intellectual Property Law (University of Southampton) and Editor (Journal of Intellectual Property Law \& Practice). Email: eleonora@e-lawnora.com.Twitter: @eLAWnora.
} 


\section{Introduction}

The possibility to seek an injunction against an intermediary whose services are used by third parties to infringe an intellectual property (IP) right has proved an important tool in the hands of rightholders, especially in an online context. ${ }^{1}$ The reason why the role of intermediaries is central is because, as Recital 59 in the preamble to Directive $2001 / 29^{2}$ (the InfoSoc Directive) explains, "[i]n the digital environment, in particular, the services of intermediaries may increasingly be used by third parties for infringing activities. In many cases such intermediaries are best placed to bring such infringing activities to an end.."

With specific regard to copyright, the same recital also states that "without prejudice to any other sanctions and remedies available, rightholders should have the possibility of applying for an injunction against an intermediary who carries a third party's infringement of a protected work or other subject-matter in a network", while stating at the same time that the conditions and modalities relating to such injunctions are a matter for the domestic law of the various EU Member States. Article 8(3) of the InfoSoc Directive consequently imposes on Member States an obligation to ensure that rightholders are in a position to apply for an injunction against intermediaries whose services are used by a third party to infringe a copyright or related right.

In a similar fashion, the third sentence in Article 11 of Directive 2004/48 (the Enforcement Directive) mandates upon Member States to ensure that rightholders are in a position to apply for an injunction against an intermediary whose services are used by a third party to infringe an IP right other than copyright or rights related to copyright. Article 3 of that directive also mandates upon Member States to ensure that measures, procedures and remedies necessary to ensure the enforcement of the IP rights covered by that directive (but this provision must be intended as also applicable to copyright and rights related to copyright ${ }^{5}$ ) are: fair; equitable; not unnecessarily complicated or costly or entail unreasonable time-limits or

\footnotetext{
${ }^{1}$ See European Commission - Directorate-General for Internal Market, Industry, Entrepreneurship and SMEs, Public consultation on the evaluation and modernisation of the legal framework for the enforcement of intellectual property rights - Summary of responses, (2016), available at http://ec.europa.eu/DocsRoom/documents/18661/attachments/1/translations/en/renditions/native, p 33.

${ }^{2}$ Directive 2001/29/EC of the European Parliament and of the Council of 22 May 2001 on the harmonisation of certain aspects of copyright and related rights in the information society, L 167, pp 10-19.

${ }^{3}$ Emphasis added.

${ }^{4}$ Directive 2004/48/EC of the European Parliament and of the Council of 29 April 2004 on the enforcement of intellectual property rights, L 195, pp 16-25.

${ }^{5}$ This is clear if one considers relevant case law of the Court of Justice of the European Union (CJEU) on intermediary injunctions in the area of copyright and rights related to copyright: see Scarlet Extended SA v Société belge des auteurs, compositeurs et éditeurs SCRL (SABAM), C-70/10, EU:C:2011:771, [36] and [48]; and Belgische Vereniging van Auteurs, Componisten en Uitgevers CVBA (SABAM) v Netlog NV, C-360/10, EU:C:2012:85, [34] and [46].
} 
unwarranted delays; effective; proportionate; and dissuasive. Such measures, procedures and remedies must be also applied in such a manner as to avoid the creation of barriers to legitimate trade and to provide for safeguards against their abuse.

UK Government implemented Article 8(3) of the InfoSoc Directive into UK law by inserting s97A into the Copyright, Designs and Patents Act 1988 (CDPA), and UK courts have ever since developed a consistent and thoughtful jurisprudence on the application of this domestic provision. However, no express implementation of the third sentence in Article 11 of the Enforcement Directive has been provided in the UK. The result has been that until the 2014 decision of the High Court of England and Wales in Cartier v BSkyB ${ }^{6}$ (Cartier) confirmed in appeal in $2016^{7}$ (Cartier CA) and applied (pending the appeal) in a similar context (Cartier 2) ${ }^{8}-$ it was uncertain whether rightholders could seek injunctions against intermediaries to block access to websites where content infringing IP rights other than copyright (more specifically: trade marks) is accessible.

The decisions of the High Court and the Court of Appeal of England and Wales in Cartier and Cartier CA, while confirming that this possibility does indeed exist under UK law, have also prompted a more thorough discussion around the role of intermediaries in an online context, including with regard to the effectiveness of alternative remedies and responsibility for bearing the costs of injunctions. These issues are also currently under discussion at the EU level, both in the context of the EU Commission's Digital Single Market Strategy (DSMS) as first unveiled in mid- $2015^{9}$ and case law of the Court of Justice of the European Union (CJEU).

This contribution intends to provide an overview of EU and UK experiences, and highlight certain trends that have emerged from relevant case law. The article is composed of four parts. The first part reviews CJEU case law in the area of intermediary injunctions, and attempts to sum up the resulting key findings. The second part considers relevant case law of UK courts in the area of blocking injunctions, and reviews the approaches taken in respect of copyright and trade marks. The third part discusses two principal issues emerged from the UK experience (the possible expansion of blocking injunctions to different areas and intermediaries, and the responsibility for the costs of injunctions), and considers whether - lacking an unambiguous legislative framework - the parallel evolution at the CJEU level may provide interpretative guidance. The fourth part highlights the terms of the current EU policy debate: notwithstanding EU harmonization efforts in the area of

\footnotetext{
${ }^{6}$ Cartier International AG and Others v British Sky Broadcasting Limited and Others [2014] EWHC 3354 (Ch).

${ }^{7}$ Cartier International AG and Others v British Sky Broadcasting Limited and Others [2016] EWCA Civ 658.

${ }^{8}$ Cartier and Another v British Sky Broadcasting Limited and Others [2016] EWHC 339 (Ch).

${ }^{9}$ European Commission, Communication from the Commission to the European Parliament, the Council, the European Economic and Social Committee and the Committee of the Regions - A Digital Single Market Strategy for Europe, COM/2015/0192 final.
} 
IP enforcement, the main finding is that there are significant gaps in the resulting framework. This prompts the question whether, under the DSMS umbrella, the EU should merely reform the current enforcement framework or, together with this, also push the boundaries of harmonization further.

\section{The EU framework, as interpreted by the CJEU}

The relevant CJEU framework on IP injunctions against intermediaries can be articulated around six principal decisions: the landmark decision in in L'Oréal v eBay ${ }^{10}\left(L^{\prime} O r e ́ a l, 2011\right)$ regarding the scope of injunctions; the twin judgments in Scarlet v SABAM ${ }^{11}$ (Scarlet, 2011) and SABAM v Netlog ${ }^{12}$ (Netlog, 2012) on the interplay between copyright injunctions and Directive $2000 / 31^{13}$ (the E-commerce Directive); the ruling in UPC Telekabel $v$ Constantin Film ${ }^{14}$ (UPC Telekabel, 2014) regarding the compatibility with EU law of blocking injunctions; and the judgments in Tommy Hilfiger v DELTA CENTER ${ }^{15}$ (Tommy Hilfiger, 2016) and Mc Fadden $v$ Sony $^{16}$ (Mc Fadden, 2016) regarding the notion of 'intermediary'.

\section{Injunctions can be aimed at both repressing existing infringements and preventing further infringements}

In L'Oréa/ the CJEU clarified the scope of injunctions available to rightholders under the third sentence in Article 11 of the Enforcement Directive. Among other things, the referring court (the High Court of England and Wales) had asked the CJEU whether this provision allows the grant of injunctions aimed not just at repressing existing infringements of IP rights, but also preventing future infringements of those rights.

The CJEU clarified at the outset how the injunctions referred to in the third sentence of Article 11 differ from those referred to in the first sentence of that provision: while the latter are addressed to infringers and intend to prohibit the continuation of an infringement ${ }^{17}$, the former are addressed to the "more complex" 18

\footnotetext{
${ }^{10}$ L'Oréal SA and Others v eBay International AG and Others, C-324/09, EU:C:2011:474.

${ }^{11}$ Scarlet Extended SA v Société belge des auteurs, compositeurs et éditeurs SCRL (SABAM), cit.

${ }^{12}$ Belgische Vereniging van Auteurs, Componisten en Uitgevers CVBA (SABAM) v Netlog NV, cit.

${ }^{13}$ Directive 2000/31/EC of the European Parliament and of the Council of 8 June 2000 on certain legal aspects of information society services, in particular electronic commerce, in the Internal Market, OJ L 178, pp 1-16.

${ }^{14}$ UPC Telekabel Wien GmbH v Constantin Film Verleih GmbH and Wega Filmproduktionsgesellschaft mbH, C-314/12, EU:C:2014:192.

${ }^{15}$ Tommy Hilfiger Licensing LLC and Others v DELTA CENTER as, C-494/15, EU:C:2016:528.

${ }^{16}$ Tobias Mc Fadden v Sony Music Entertainment Germany GmbH, C-484/14, EU:C:2016:689.

${ }^{17}$ L'Oréal, [128].
} 
situation of intermediaries whose services are used by third parties to infringe the applicant's IP rights. Also taking into account the overall objective of the Enforcement Directive, ie to ensure an effective protection of IP rights ${ }^{19}$, alongside the provision in Article 18 of the E-commerce Directive ${ }^{20}$ and Recital 24 in the preamble to the Enforcement Directive ${ }^{21}$, the court concluded - contrary to the more limited view expressed by Advocate General (AG) Jääskinen in his Opinion ${ }^{22}$ - that the jurisdiction conferred by the third sentence in Article 11 of the Enforcement Directive allows national courts to order an intermediary to take measures that contribute not only to terminate infringements committed through its services, but also prevent further infringements. ${ }^{23}$

Some commentators have inferred from this conclusion the opportunity for intermediaries to consider preemptive action to avoid being subject to an injunction in the future. ${ }^{24}$ Such considerations may be read in parallel to those that Arnold J undertook in Cartier. There, the UK judge recalled that the stance in Recital 59 in the preamble to the InfoSoc Directive postulates that the economic logic of granting injunctions against intermediaries such as internet service providers (ISPs) is that they are the 'lowest cost avoiders' of infringement. Accordingly, "it is economically more efficient to require intermediaries to take action to prevent infringement occurring via their services than it is to require rightholders to take action directly against infringers." ${ }^{25}$ This might suggest - yet possibly with a slight interpretative stretch of the literal wording of the judgment - that the voluntary ${ }^{26}$ implementation of filtering system by intermediaries might be an economically efficient initiative.

\footnotetext{
18 L'Oréal, [129].

${ }^{19}$ L'Oréal, [131] referring to Productores de Música de España (Promusicae) v Telefónica de España SAU, C-275/06, EU:C:2008:54, [43].

${ }^{20}$ L'Oréal, [132]-[133]. This provision requires Member States "to ensure that court actions available under their national law concerning information society services' activities allow for the rapid adoption of measures designed to terminate any alleged infringement and to prevent any further impairment of the interests involved."

${ }^{21}$ L'Oréal, [134]. Recital 24 states that "depending on the particular case, and if justified by the circumstances, measures aimed at preventing further infringements of intellectual property rights must be provided for."

${ }^{22}$ Opinion of Advocate General Niilo Jääskinen in L'Oréal SA and Others v eBay International AG and Others, C-324/09, EU:C:2010:757, [175] and [181].

${ }^{23}$ L'Oréal, [131]. According to E Bonadio, 'Trade marks in online marketplaces: the CJEU's stance in L'Oreal v eBay (2012) 18(2) CTLR 37,41 , this conclusion goes beyond a literal interpretation of Article 11 of the Enforcement Directive, but holding otherwise would have been at odds with both Recital 24 and Article 3(2) therein. In a similar sense, see T Headdon, 'Beyond liability: on the availability and scope of injunctions against online intermediaries after L'Oreal v Ebay (2012) 34(3) EIPR 137, 138.

${ }^{24} \mathrm{~F}$ Rizzuto, 'The liability of online intermediary service providers for infringements of intellectual property rights' (2012) 18(1) CTLR $4,11$.

${ }^{25}$ Cartier, [251].

${ }^{26}$ The imposition of general monitoring obligations appears currently forbidden by Article 15 of the E-commerce Directive, but cf European Commission, Proposal for a directive of the European Parliament and of the Council on copyright in the Digital Single Market, $\operatorname{COM(2016)} 593$ final, Recital 38 and Article 13.
} 


\section{Injunctions against intermediaries must comply with a number of legislative sources and principles}

In L'Oréal the CJEU also recalled that the conditions to be met and the procedure to be followed when issuing an injunction against an intermediary are a matter for national law. ${ }^{27}$ In any case, however, domestic rules must be designed in such a way that the objective pursued by the Enforcement Directive may be achieved $^{28}$, including to ensure - as Article 3(2) mandates - that the measures concerned are effective ${ }^{29}$ and dissuasive. ${ }^{30}$

Considering the specific case of the UK, ie a Member State that has not given expression implementation to the third sentence in Article 11, the CJEU noted how courts must, when applying national law, do so in compliance with the so called Marleasing principle. ${ }^{31}$ This means that, in the specific case of injunctions against intermediaries, when considering an application a court should take into account the wording and the purpose the third sentence of Article $11^{32}$, as well as: the principles set in Article 3 of the Enforcement Directive $^{33}$ (including the principle of proportionality) $)^{34}$; the existence of prohibition of a general monitoring obligation on online intermediaries pursuant to Article 15 of the E-commerce Directive read in conjunction with Article 2(3) of the Enforcement Directive ${ }^{35}$; and the need to strike a fair balance between the various rights and interests at issue. ${ }^{36}$

\footnotetext{
27 L'Oréal, [135].

28 L'Oréal, [137].

${ }^{29}$ The effectiveness requirement is to be read in conjunction with Recital 3 in the preamble to the Enforcement Directive, and its origin may be traced to Article 19(1) of the Treaty on the Functioning of the European Union (consolidated version 2012), OJ C 326, pp 47-200: see J Riordan, The liability of internet intermediaries (OUP:2016), p 434.

30 L'Oréal, [137].

${ }^{31}$ Marleasing SA v La Comercial Internacional de Alimentacion SA, C-106/89, EU:C:1990:395, [8]. On this general principle of EU law, see further P Craig - G de Búrca, EU law - Text, cases, and materials, $6^{\text {th }}$ edn (OUP:2015), pp 211-212.

32 L'Oréal, [137].

${ }^{33}$ L'Oréal, [140].

${ }^{34}$ Some commentators have seen proportionality in EU copyright remedies as akin to a 'mega standard' aimed at balancing the internal traditional interests vis-à-vis the new challenges posed by the fundamental rights discourse. In this sense see $O$ Fischman Afori, 'Proportionality: a new mega standard in European copyright law' (2014) 45(8) IIC 889, pp 901-904.

${ }^{35}$ L'Oréal, [139].

${ }^{36}$ L'Oréal, [143] recalling Productores de Música de España (Promusicae) v Telefónica de España SAU, cit, [65]-[68]. As noted by Riordan, 'The liability', cit, p 414, pursuant to Article 52(1) of the Charter of Fundamental Rights of the European Union, OJ C 364, pp 1-22, a requirement of necessity theoretically applies to any remedy that engages Charter rights.
} 
With specific regard to copyright, the CJEU considered the interplay between intermediary injunctions, Article 15 of the Ecommerce Directive, and fundamental rights in its twin decisions in Scarlet and Netlog. Both references for a preliminary ruling from Belgian courts (the Brussels Court of Appeal and the Brussels Court of First Instance, respectively), these cases required the CJEU to consider whether an intermediary (an access provider and a social networking site, respectively) could be the addressee of an injunction that would require it to introduce a system for filtering: all electronic communications passing via its services; which would apply indiscriminately to all its customers; as a preventive measure; exclusively at its expense; and for an unlimited period. The CJEU answered in the negative, noting how preventative monitoring of this kind would be incompatible - among other things - with Article 15 of the E-commerce Directive, in that it would require active observation of all electronic communications conducted on the network of the intermediary concerned and, consequently, would encompass all information to be transmitted and all customers using that network. ${ }^{37}$ The CJEU also held that, while the protection of IP is enshrined in Article 17(2) of the Charter of Fundamental Rights of the European Union ${ }^{38}$ (Charter), other fundamental rights must be also considered, ${ }^{39}$ including intermediaries' freedom to conduct a business as per Article 16 of the Charter $^{40}$ and their customers' right to protection of their personal data (Article 8 of the Charter) and their freedom to receive or impart information (Article 11 of the Charter). ${ }^{41}$ With particular regard to intermediaries' freedom to conduct a business, the CJEU noted how a filtering system of the kind at stake in the national background proceedings would require the installation of a complicated, costly, permanent computer system at the own expense of the intermediary concerned, and this which would also be contrary to the conditions laid down in Article 3(1) of the Enforcement Directive. ${ }^{42}$ Overall, the twin judgments in Scarlet and Netlog make it clear that the fundamental rights discourse is central to the assessment of intermediary liability and relevant remedies ${ }^{43}$, although some commentators have seen Article 16 of the Charter as providing limited assistance to intermediaries in this specific context. ${ }^{44}$

\footnotetext{
${ }^{37}$ Scarlet, [39]. In the same sense, Netlog, [38].

${ }^{38}$ Charter of Fundamental Rights of the European Union, cit (Scarlet, [43]). In the same sense, Netlog, [41].

${ }^{39}$ Scarlet, [44] recalling Productores de Música de España (Promusicae) v Telefónica de España SAU, cit, [62]-[68]. In the sense sense, Netlog, [43].

${ }^{40}$ Scarlet, [46]. In the same sense, Netlog, [44].

${ }^{41}$ Scarlet, [50]. In the same sense, Netlog, [48].

${ }^{42}$ Scarlet, [48]. In the same sense, Netlog, [46].

${ }^{43}$ See C Angelopolous, 'Are blocking injunctions against ISPs allowed in Europe? Copyright enforcement in the post-Telekabe/ EU legal landscape’ (2014) 9(10) JIPLP 812, p 814.

${ }^{44}$ See KT O'Sullivan, 'Enforcing copyright online: internet service provider obligations and the European Charter of Human Rights' (2014) 36(9) EIPR 577, pp 581-582.
} 


\section{Blocking injunctions are allowed under EU law}

In UPC Telekabe/ the CJEU had been asked to clarify - among other things - whether a particular type of intermediary injunction, consisting of an order on an access provider to block access for its customers to a certain website where unlicensed copyright content is available, ie a blocking injunction, would be compatible with the fundamental rights recognized by EU law. In this sense, question was also whether relevant provisions under EU law, ie Article 8(3) of the InfoSoc Directive and Article 11 of the Enforcement Directive, provide an adequate legislative basis for website blocking orders. ${ }^{45}$

The CJEU recalled - yet without providing any specific guidance on how to undertake the relevant assessment ${ }^{46}$ - that, where several fundamental rights are at issue, a fair balance between them must be struck. ${ }^{47}$ In the case at hand, the fundamental rights to consider would be: copyright and rights related to copyright, which are protected under Article 17(2) of the Charter; freedom to conduct a business, which economic agents such as online intermediaries enjoy under Article 16 of the Charter; and the freedom of information of internet users, whose protection is ensured by Article 11 of the Charter. ${ }^{48}$ The CJEU acknowledged that, on the one hand, a blocking injunction would compress an intermediary's freedom to conduct a business ${ }^{49}$ but, on the other hand, an injunction of this kind would not infringe the very substance of such freedom. ${ }^{50}$ This would be so for two principal reasons: first, a blocking order would leave its addressee free to determine the specific measures to be taken in order to achieve the result sought ${ }^{51}$ (in his Opinion AG Cruz Villalón had instead held the view that a mere outcome prohibition not specifying the measures that the addressee of a blocking injunction must take would be incompatible with EU fundamental rights ${ }^{52}$; secondly, an intermediary could avoid liability by proving that he has taken all reasonable measures. ${ }^{53}$ In any case, however, while an intermediary must adopt measures that are sufficiently effective to ensure genuine protection of copyright ${ }^{54}$, such measures must be also strictly targeted, in the sense that

\footnotetext{
${ }^{45}$ Answering in the affirmative, see R Arnold 'Website-blocking injunctions: the question of legislative basis' (2015) 37(10) EIPR, 623, p 630 .

${ }^{46}$ In this sense also Angelopolous, 'Are blocking injunctions', cit, p 815.

${ }^{47}$ UPC Telekabel, [46].

${ }^{48}$ UPC Telekabel, [47].

${ }^{49}$ UPC Telekabel, [50]

${ }^{50}$ UPC Telekabel, [51].

${ }^{51}$ UPC Telekabel, [52].

52 Opinion of Advocate General Pedro Cruz Villalón in UPC Telekabel Wien GmbH v Constantin Film Verleih GmbH and Wega Filmproduktionsgesellschaft mbH, C-314/12, EU:C:2013:781, [84]-[90]

${ }^{53}$ UPC Telekabel, [53].

${ }^{54}$ UPC Telekabel, [62].
} 
they must serve to bring an end to a third party's infringement of copyright or of a related right but without thereby affecting internet users who are using the provider's services in order to access lawfully information..$^{55}$

\section{The notion of 'intermediary' is broad}

A final principle that can be inferred from relevant CJEU case law on intermediary injunctions is that the notion of 'intermediary' itself is a broad one.

In Tommy Hilfiger the CJEU had been asked to consider whether the tenant of market halls who sublets the various sales points situated in those halls to market-traders, some of whom use their pitches in order to sell counterfeit goods of branded products, falls within the concept of "an intermediary whose services are being used by a third party to infringe an intellectual property right" as per the third sentence in Article 11 of the Enforcement Directive and, if so, be subject to the measures envisaged by that provision. Recalling its earlier judgment in UPC Telekabe ${ }^{6}$, the CJEU noted that for an economic operator to fall within the classification of 'intermediary' it is sufficient that he provides - even among other things $5^{57}$ - a service capable of being used by one or more other persons in order to infringe one or more IP rights. The court concluded that injunctions pursuant to the third sentence in Article 11 of the Enforcement Directive are also available against operators of physical marketplaces and, while Member States are free to determine the conditions to be met and to the procedure to be followed for injunctions in these $\operatorname{cases}^{58}$, the principles set in Article 3 of the Enforcement Directive would be also applicable to such situations. ${ }^{59}$

In Mc Fadden ${ }^{60}$ the CJEU had been asked to determine whether a service consisting in making available to the general public an open wireless communication network free of charge could be regarded as an 'information society service' within the meaning of Article 12(1) of the Ecommerce Directive. By means of a combined reading of relevant provisions in Directive 98/48 ${ }^{61}$, Article 57 of the Treaty on the Functioning of

\footnotetext{
${ }^{55}$ UPC Telekabel, [56].

${ }^{56}$ Tommy Hilfiger, [23], recalling UPC Telekabel, [32] and [35].

${ }^{57}$ Tommy Hilfiger, [24].

${ }^{58}$ Tommy Hilfiger, [32] referring to L'Oréal, [135].

${ }^{59}$ Tommy Hilfiger, [36].

${ }^{60}$ See further below, sub §III.

${ }^{61}$ Directive 98/48/EC of the European Parliament and of the Council of 20 July 1998 amending Directive 98/34/EC laying down a procedure for the provision of information in the field of technical standards and regulations, OJ L 217, pp 18-26 (Mc Fadden, [37][38]).
} 
the European Union ${ }^{62}$, and the E-commerce Directive ${ }^{63}$ the CJEU concluded that the economic nature of a service provided, even free of charge, can be inferred for factors other than the fact that the service is paid for by those for whom it is performed ${ }^{64}$, eg by the fact that the free nature is justified by the purpose to advertise goods sold and services provided by that service provider. ${ }^{65}$

\section{The UK experience}

\section{Copyright blocking injunctions}

By adopting s97A CDPA, UK Government gave express implementation to Article 8(3) of the InfoSoc Directive. This domestic provision states that the High Court of England and Wales (in Scotland, the Court of Session) has power to grant an injunction against a service provider, where that service provider has actual knowledge of another person using their service to infringe copyright. The second paragraph in s97A further provides that, in determining whether a service provider has actual knowledge, a court must take into account all matters that appear to it in the particular circumstances to be relevant and, among other things, have regard to whether a service provider has received a sufficiently detailed notice.

In 2011 the High Court of England and Wales utilized s97A CDPA to grant the first injunction to block access to a website. In Twentieth Century Fox $v B T^{66}$ (Newzbin 2) a group of film studios sought an injunction against the largest internet service provider in the UK (BT) to block or at least impede access by BT's subscribers to a website (Newzbin 2) that had been resurrected ${ }^{67}$ despite a previous action successfully brought in the UK (Newzbin $1^{68}$ ). With particular regard to the requirement of 'actual knowledge', Arnold J deemed that what must be shown is that the service provider has actual knowledge of one or more persons using its service to infringe copyright. ${ }^{69}$ While relevant, it is not essential to prove actual knowledge of a specific infringement of a specific copyright work by a specific individual. ${ }^{70}$ In considering whether a service

\footnotetext{
${ }^{62}$ Treaty on the Functioning of the European Union (consolidated version 2012), cit (Mc Fadden, [37])

${ }^{63}$ Mc Fadden, [40].

${ }^{64}$ Mc Fadden, [41], referring to Sotiris Papasavvas v O Fileleftheros Dimosia Etaireia Ltd and Others, C-291/13, EU:C:2014:2209, [28][29].

${ }^{65}$ Mc Fadden, [42].

${ }^{66}$ Twentieth Century Fox Film Corporation and Others v British Telecommunications PIc [2011] EWHC 1981 (Ch).

${ }^{67}$ Newzbin 2, [2].

${ }^{68}$ Twentieth Century Fox Film Corporation and Others v Newzbin Limited [2010] EWHC 608 (Ch).

${ }^{69}$ Newzbin 2, [148].

${ }^{70}$ Newzbin 2, [148].
} 
provider has actual knowledge, it is necessary to consider whether the service provider has been given notice of the infringement by means of a sufficiently detailed notice. ${ }^{71}$ Having reviewed additional conditions, including whether the order sought would be effective and proportionate, Arnold I granted the order requested.

Since 2011, the High Court of England and Wales has ordered to block access to more than five hundred websites, with applications being filed by an increasingly diverse group of copyright owners, including the record industry, publishers, and the Football Association Premier League. ${ }^{72}$ By considering the UK experience, a recent economic study has suggested that ongoing site blocking has had a statistically and economically significant impact on consumer behaviour, and mitigated the possibility of a long-term return to the prior status quo when it comes to online copyright infringement. ${ }^{73}$

Of particular interest for the present discussion are the reasons given by Arnold $\mathrm{J}$ in Newzbin 2 for determining responsibility for the costs of an injunction. According to the judge, "the rather unusual nature of the remedy under Article $8(3)^{174}$ means that it is reasonable for an (innocent) intermediary to require a court order for its own protection, and require the relevant copyright owners to adduce sufficient evidence to establish both that the court had jurisdiction to make the order and that it is appropriate in the exercise of the court's discretion to do so. It follows that the costs of an application for a blocking order should be borne by the applicant. ${ }^{75}$ However, the costs of implementing a blocking order should be borne by the addressee of the injunction. The reason is that an intermediary is a commercial enterprise that makes a profit from the provision of the services that the operators and users of target websites use to infringe the applicants' IP rights. Accordingly,

"the costs of implementing the order can be regarded as a cost of carrying on that business. It seems ... to be implicit in recital (59) of the Information Society Directive that the European legislature has chosen to impose that cost on the intermediary. Furthermore, that interpretation appears to be

\footnotetext{
${ }^{71}$ Newzbin 2, [149].

72 D Meale, '500 and counting: websites blocked by order of UK courts' (29 July 2015) The IPKat, available at http://ipkitten.blogspot.it/2015/07/500-and-counting-websites-blocked-by.html.

${ }^{73}$ B Danaher and Others, Website blocking revisited: the effect of the UK November 2014 blocks on consumer behavior (2016), available at https://techpolicyinstitute.org/wp-content/uploads/2016/04/UK-Blocking-2-0-2016-04-06-mds.pdf. Arguing that website blocking is not effective see, instead, J Poort and Others, 'Baywatch: Two approaches to measure the effects of blocking access to The Pirate Bay' (2014) 38 Telecommunications Policy 383.

74 Newzbin 2, [53].

${ }^{75}$ Newzbin 2, [53].
} 
supported by the Court of Justice's statement in L'Oréal v eBay at [139] that such measures "must not be excessively costly"."176

\section{Trade mark blocking injunctions}

As mentioned above, unlike Article 8(3) of the InfoSoc Directive, UK Government did not take any specific steps to transpose the third sentence of Article 11 of the Enforcement Directive into its own national law. In his 2009 decision in $L^{\prime}$ Oréal ${ }^{77}$ Arnold J concluded ${ }^{78}$ that, despite lack of an express implementation, the High Court of England and Wales had power under s 37(1) of the Senior Courts Act 1981 (SCA, formerly known as the Supreme Court Act 1981) to grant an injunction against an intermediary whose services had been used by third parties to infringe an IP right (specifically: a registered trade mark), to the extent that this is what the third sentence in Article 11 of the Enforcement Directive requires.

In the aftermath of the UK decision in L'Oréal it remained unclear whether s37(1) SCA could be used to obtain a particular type of injunction, ie an injunction against an intermediary to block access to a website where content that infringes IP rights other than copyright can be found. Possibly unsurprisingly (considering the previous stance of Arnold J in L'Oréal), the High Court of England and Wales (again, Arnold J) answered this question in the affirmative in its 2014 decision in Cartier.

That case concerned an application by a number of trade mark owners for an injunction against the five main retail internet service providers in the UK that would require them to block, or at least impede, access by their respective subscribers to a number of websites that advertised and sold counterfeit goods. The applicants contended that the operators of such websites infringed their trade marks, but did not suggest that the intermediaries targeted by the application would infringe the trade marks or be liable for the infringements by the operators of the target websites. Arnold J reviewed the choice of UK Government not to give express implementation to the third sentence of Article 11 at the time of transposing the Enforcement Directive into its own legal system. Government had done so on belief that no action was required $^{79}$ : while UK Government had deemed necessary to give express implementation to Article 8(3) of the InfoSoc Directive ${ }^{80}$, it did not do the same with regard to the third sentence in Article 11 of the Enforcement Directive by referring to the existence of s37(1) SCA.

\footnotetext{
${ }^{76}$ Newzbin 2, [32].

77 L'Oréal SA and Others v eBay International AG and Others [2009] EWHC 1094 (Ch).

78 L'Oréal v eBay [2009] EWHC 1094 (Ch), [447]-[454].

${ }^{79}$ Cartier, [116]. All this despite an earlier view of the Government to the contrary: see Cartier, [113].

${ }^{80}$ Cartier, [115].
} 
The judge provided an interpretation of s37(1) SCA both in a domestic context ${ }^{81}$ and in light of the third sentence of Article 11 in the Enforcement Directive ${ }^{82}$, and concluded that in principle the High Court of England and Wales would have jurisdiction to grant the order requested by the applicants. The judge added that in any case the court's discretion under S37(1) SCA to grant website blocking orders is not unlimited, but must be exercised consistently with the terms of the Enforcement Directive, including Articles 3 and 11, and with the terms of the E-commerce Directive, including Articles 12 to $15 .{ }^{83}$

A number of threshold conditions must be therefore satisfied: first, the ISPs against whom the order is sought must be intermediaries within the meaning of the third sentence of Article 11; secondly, either the users or the operators of the website must be infringing the claimants' IP rights; thirdly, the users or the operators of the website must use the services of the intermediary; fourthly, the provider must have actual knowledge of this. The first three conditions follows from the wording of Article 11 itself. The fourth follows from the E-commerce Directive, for if ISPs could be required to block websites without having knowledge of the infringing activity then this would effectively impose on them an obligation to monitor. ${ }^{84}$

In addition to such threshold conditions, also a number of principles must be applied when considering whether to make a website blocking order, namely the relief must: (i) be necessary; (ii) be effective; (iii) be dissuasive; (iv) not be unnecessarily complicated or costly; ( $v$ ) avoid barriers to legitimate trade; (vi) be fair and equitable and strike a 'fair balance' between the applicable fundamental rights; and (vii) be proportionate. $^{85}$

Arnold J concluded that the order sought by the applicants could be granted, and added that in the current stage of technological evolution there are no real alternatives to blocking. ${ }^{86}$ Website blocking is superior to other options, including - among other things - notice-and-takedown by hosts, payment freezing, and deindexing from search engines. With regard to notice-and-takedown, Arnold J stated "that website blocking has advantages over notice-and-takedown" ${ }^{187}$, also accepting a concern often raised by rightholders, ie that

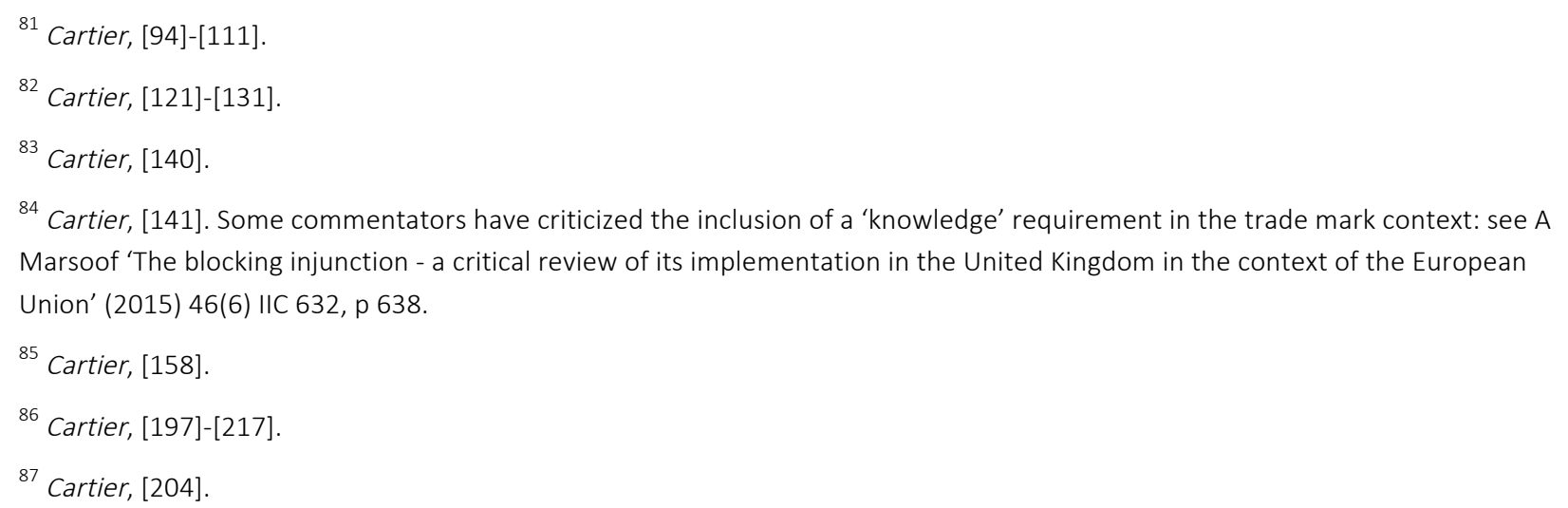


"as soon as an offending website is taken down by one host, the almost invariable response of the operator is to move the website to a different host. ${ }^{188}$ Turning to payment freezing, the judge was skeptical as to its actual effectiveness, in that he was "not persuaded that this is a realistic alternative measure in general, although there may be particular cases where it has some value. ${ }^{189}$ Finally, with regard to de-indexing, while "this is potentially an important weapon"90, "it is not a realistic alternative measure"91, also because "search engines are not willing to de-index entire websites ... without a court order" and - following the CJEU judgment in Google Spain v AEPD ${ }^{92}$ - "it is not clear at present that any EU court would have power to order de-indexing on the basis of intellectual property infringement. ${ }^{193}$ Contrary to a Dutch study ${ }^{94}$ extensively criticized by Arnold J95, "in the section 97A, blocking of targeted websites has proved reasonably effective in reducing use of those websites in the UK. ${ }^{96}$ No doubt it is the casual, inexperienced or lazy users who stop visiting those websites, whereas the experienced and determined users circumvent the blocking measures; but that does not mean that it is not a worthwhile outcome. ${ }^{197}$ In sum, none of current alternatives is as effective as blocking orders ${ }^{98}$, and also the "risk of reputational damage to the ISPs, particularly in the event of over-blocking" does not appear a "significant one". ${ }^{99}$ In any case, it would not be incumbent on the rightholder to show that the blocking measures would lead to a reduction in the overall level of infringement." ${ }^{100}$

In line with his earlier judgment in Newzbin 2, Arnold J also took the view that "the rightholders should pay the costs of an unopposed application ... [and] the ISPs should generally bear the costs of implementation as part of the costs of carrying on business in this sector". However the judge did "not rule out the possibility of ordering the rightholder to pay some or all of the implementation costs in an appropriate case." ${ }^{101}$

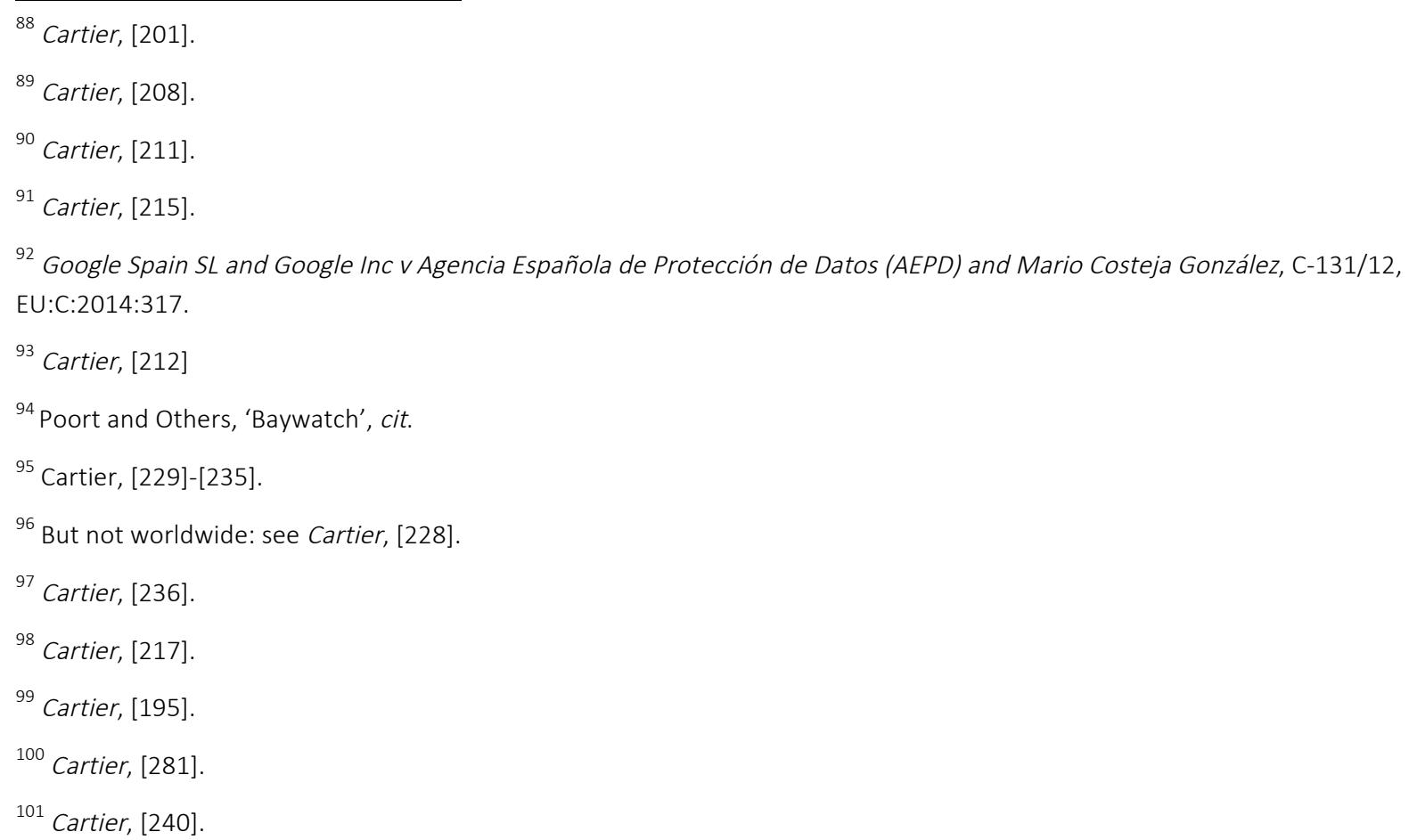


The "entirely correct"102 decision of Arnold J was confirmed in appeal. Kitchin $L J$ (delivering the judgment of the Court of Appeal of England and Wales) recognized that "the ISPs are not guilty of any wrongdoing", nor owe a common law duty of care to take reasonable care to ensure that their services are not used by the operators of the offending websites. ${ }^{103}$ This said, however, Kitchin $L$ observed that the operators of the infringing websites need the services of the ISPs in order to offer for sale and sell their counterfeit goods to UK consumers. It follows that "the ISPs are therefore inevitable and essential actors in those infringing activities." ${ }^{104}$ Kitchin LJ also dismissed the ISPs' point that Arnold J allegedly failed to carry out a fair evaluation of the relative merits of alternative measures to blocking ${ }^{105}$, and confirmed that that Arnold J "was entitled to require the ISPs to bear the costs of the implementation of the orders in issue. ${ }^{106} \mathrm{He}$ also approved of Arnold J's proper consideration of the economic impact of website blocking orders upon the businesses of the ISPs, and that these could either bear these costs themselves or pass them on to their subscribers in the form of higher subscription charges. ${ }^{107}$

The Court of Appeal judgment contains however the dissent of Briggs $L J$ on the issue of costs. In particular, "the cost burden attributable to the implementation of a particular blocking order should fall upon the rightholder making the application for it. ${ }^{108}$ According to Briggs $L J$, the reason is a domestic one. It is true that both the Enforcement Directive and the InfoSoc directives provide that rightholders should have the possibility of applying for an injunction against an intermediary who either carries a third party's infringement of a protected work in a network (in copyright cases) or whose services are being used by a third party to infringe the rightholder's industrial property right (in relation to trade marks). In both cases the conditions and modalities relating to such injunctions, or the conditions and procedures relating to such injunctions should be left to the national law of the Member States. ${ }^{109}$ In the UK, however, courts have jurisdiction as per $\mathbf{3 7 7 ( 1 ) ~ S C A}$, and this in substance reflects an originally unfettered jurisdiction exercised by the Court of Chancery on equitable principles. In the case of orders against innocent third parties, the law

\footnotetext{
${ }^{102}$ Cartier CA, [35].

${ }^{103}$ Cartier CA, [54].

${ }^{104}$ Cartier CA, [56].

${ }^{105}$ Cartier CA, [177]-[180].

${ }^{106}$ Cartier CA, [150].

${ }^{107}$ Cartier CA, [169].

${ }^{108}$ Cartier CA, [198].

${ }^{109}$ Cartier CA, [199].
} 
has evolved so to ensure that a standard condition or 'modality' for the grant of an injunction is that the cost reasonably incurred by the innocent respondent should be reimbursed by the applicant. ${ }^{110}$ Accordingly,

"[T]he reason why the courts of England and Wales have jurisdiction to make blocking orders of the relevant type is that they are indeed a natural development of the court's enforcement of the equitable duty to assist so that, in the context of trade marks, the government was right to conclude that no specific legislation for that purpose was required ... [T] he courts could and probably would have developed this jurisdiction regardless of the requirement in the two Directives that it be made available as specified. It was a jurisdiction with existing well-recognised conditions or modalities, one of which was that the victim indemnify the innocent party for its cost of complying with the court's order."111

\section{EU implications of UK jurisprudence on blocking injunctions}

From the UK experience, there appear to be two main threads worth discussing further in light of existing CJEU case law and the ongoing EU IP enforcement reform debate. First, whether use of the general power of injunctive relief of the High Court of England and Wales to grant a blocking injunction in a trade mark case might mean that injunctions of this kind might become more frequent and be addressed at intermediaries other than access providers. Secondly, whether the intermediaries to which blocking injunctions are addressed should be the ones bearing the relevant implementations costs. Although Briggs $L J$ rooted his dissent within domestic law, the issue of responsibility for the costs of an injunction has been raised both in the EU context and outside the EU, eg - recently - in Australia. ${ }^{112}$

\section{Floodgates to open?}

Use of the general power of the High Court to grant injunctive relief to give effect to the third sentence of Article 11 of the Enforcement Directive prompts two main questions: first, whether - in the aftermath of the Cartier decisions - the number of applications for intermediary blocking injunctions will increase; and, secondly, whether injunctions will target intermediaries other than access providers, eg payment providers.

\footnotetext{
${ }^{110}$ Cartier CA, [202].

${ }^{111}$ Cartier CA, [205].

${ }^{112}$ The first blocking order in Australia was granted in late 2016: see Roadshow Films Pty Ltd $v$ Telstra Corporation Ltd [2016] FCA 1503 (also including a discussion of costs).
} 
The idea that the number of applications for IP blocking injunctions will raise appears justified in light of both parallel experience in relation to s97A CDPA and consideration that applications for injunctions are in general successful. ${ }^{113}$ However, it is worth noting how - both in s97A CDPA cases and the Cartier judgments - the actual grant of an injunction against an intermediary is subject to a number of threshold conditions, as well as several principles. All this suggests that after Cartier and Cartier CA other trade mark owners will likely apply for blocking injunctions (also considering relevant data that suggests that the number of IP infringements has increased ${ }^{114}$ ) but - in any case - the conditions and principles set by Arnold J (as confirmed in appeal) will require close scrutiny of relevant applications. Similarly to the case of s97A CDPA applications, it is however foreseeable that the High Court will establish streamlined procedures to handle applications for blocking injunctions in cases other than copyright. Similarly to the case of s97A CDPA orders, it is also foreseeable that the type of rightholders seeking an injunction to block access to websites selling counterfeits will become more diverse, and include owners of trade marks for goods other than luxury ones (as it was instead the case of Cartier).

Turning to the question whether intermediaries other than access providers might be the addressees of future injunctions, the answer also appears to be in the affirmative. This follows from consideration of relevant practices, as well as the recent CJEU decisions in Tommy Hilfiger and Mc Fadden. The former decision, as also mentioned above, clarifies that: first, the notion of 'intermediary' is a broad one; secondly, no direct relationship is needed between the intermediary and the infringer; thirdly, injunctions within the third sentence in Article 11 of the Enforcement Directive can be sought indistinctly in the analogue and digital realms. In this sense, the expansive stance taken in Tommy Hilfiger suggests that its principles may find application in relation to IP rights other than trade mark, and also marketplaces of various kinds. ${ }^{115} \mathrm{Mc}$ Fadden suggests instead that different types of intermediaries can be the addressees of relevant injunctions. This finding is in line with evidence that suggests that rightholders in individual Member States have increasingly sought injunctions against a broad range of intermediaries, including access providers, content hosting platforms, search engines, online marketplaces, data storage provider and domain name registrars and registries, as well as retailer and wholesaler. ${ }^{116}$ In the specific case of the UK, the issue of qualification of

\footnotetext{
${ }^{113}$ European Commission - Directorate-General for Internal Market, Industry, Entrepreneurship and SMEs, Public consultation on the evaluation and modernisation of the legal framework for the enforcement of intellectual property rights - Summary of responses, (2016), cit, p 33.

${ }^{114}$ European Commission - Directorate-General for Internal Market, Industry, Entrepreneurship and SMEs, Public consultation on the evaluation and modernisation of the legal framework for the enforcement of intellectual property rights - Summary of responses, (2016), cit, p 33.

${ }^{115}$ See M Hecht - B Clark, 'Landlord liability for IP infringements: CJEU holds that operators of physical marketplace are intermediaries under the Enforcement Directive in Tommy Hilfiger (C-494/15)' (2016) 38(11) EIPR 703, p 705.

${ }^{116}$ European Commission - Directorate-General for Internal Market, Industry, Entrepreneurship and SMEs, Public consultation on the evaluation and modernisation of the legal framework for the enforcement of intellectual property rights - Summary of responses, (2016), cit, p 33.
} 
someone as an 'intermediary' may be in any case less important than elsewhere, on consideration that except for copyright - the relevant legal basis for injunctions, ie s37(1) SCA, simply allows the High Court to grant an injunction in all cases in which it appears to the court to be just and convenient to do so, without the need to conduct any assessment on the qualification of the potential addressee as an intermediary. ${ }^{117}$

\section{Is there an EU rule on injunctions' implementation costs?}

Similarly to Arnold J, Kitchin $L J$ confirmed that online intermediaries are to bear the costs of implementing a blocking order, while rightholders have to pay the costs of the relevant application. In his dissent Briggs $L J$ stated to agree with the analysis of Kitchin $L$, except on the issue of costs. The appeal in Cartier was the first time that ISPs had ever appealed a blocking order (including those made pursuant to s97A CDPA), also in relation to costs.

The conclusion that intermediaries are to bear the costs of implementing blocking injunctions is supportedyet only implicitly - by EU law. The EU law framework is in fact fundamentally silent regarding who should bear the costs of injunctions against intermediaries. Even the ambiguous wording of Article 14 of the Enforcement Directive ("Member States shall ensure that reasonable and proportionate legal costs and other expenses incurred by the successful party shall, as a general rule, be borne by the unsuccessful party, unless equity does not allow this.") does not seem to relate directly to injunctions. Substantially the issue of injunction costs appears to be an area of the law that has been left unharmonized at the EU level. This is possibly also because, as Recital 59 of the InfoSoc Directive eloquently puts, "[t]he conditions and modalities relating to such injunctions should be left to the national law of the Member States." Although the majority of national legal systems envisages that intermediaries are responsible for bearing the costs of an injunction against them for third-party infringements, Member States are ultimately free to choose the solution they prefer. As such, any discussion as to whether the solution indicated by Arnold J and subsequently followed in other cases is the one to prefer is a legitimate one. This is particular the case after the recent CJEU decision in Mc Fadden.

Mc Fadden was a reference for a preliminary ruling from the Regional Court, Munich I (Germany), and was made in the context of proceedings between Sony and an individual (Tobias Mc Fadden) who operated a business selling and renting lighting and sound systems for various events. Mc Fadden owned a Wi-Fi connection that was open to anyone to use as it was not protected by any password. In 2010 that

\footnotetext{
${ }^{117}$ This was the position that Sir Richard Arnold expressed during his keynote address at a conference held in 2015 at the University of Southampton: see E Rosati, 'Who is an intermediary for the sake of Article 11 of the Enforcement Directive?' (18 September 2015) The IPKat, available at http://ipkitten.blogspot.it/2015/09/who-is-intermediary-for-sake-of-article.html.
} 
connection was used by someone other than Mc Fadden to download unlawfully a musical work to which Sony owns the copyright. Following Sony's formal notice, Mc Fadden sought a negative declaration from the referring court. This dismissed it and upheld Sony's counterclaim, granting an injunction against Mc Fadden on the ground of his direct liability for the infringement at issue and ordering him to pay damages, the costs of the formal notice, and costs. Mc Fadden appealed that decision, arguing that the provisions of German law transposing Article 12(1) of the E-commerce Directive would shield him from liability for third-party infringements. The Regional Court held the view that Mc Fadden would not be directly liable, but rather indirectly liable according to the German doctrine of Störerhaftung, on the ground that his Wi-Fi network had not been made secure. The court decided nonetheless to stay the proceedings and seek guidance from the CJEU on a number of issues, including the following:

"Is ... Article 12(1) of [the E-commerce Directive] to be interpreted as meaning that the expression 'not liable for the information transmitted' precludes as a matter of principle, or in any event in relation to a first established copyright infringement, any claims for injunctive relief, damages or the payment of the costs of giving formal notice or court costs which a person affected by a copyright infringement might make against the access provider?"

In his Opinion on 16 March $2016^{118}$ AG Szpunar held the view that an intermediary cannot be held liable for an IP infringement committed by a user of its services and, as a result, cannot be asked to bear pre-litigation and court costs. Holding otherwise "could potentially have the same punitive effect as an order to pay damages and could in the same way hinder the development of the intermediary services in question." ${ }^{119}$ The AG further noted that injunctions may be imposed on innocent intermediaries to repress third-party infringements. ${ }^{120}$ However, the safe harbour regime (within Article 12 of the E-commerce Directive in that specific case) "precludes the making of orders against intermediary service providers not only for the payment of damages, but also for the payment of the costs of giving formal notice or other costs relating to copyright infringements committed by third parties as a result of the information transmitted."121 The phrase 'other costs' might encompass the costs of implementing an injunction, including a blocking injunction. The statement of the AG in this part of the Opinion, in fact, does not appear to distinguish

\footnotetext{
${ }^{118}$ Opinion of Advocate General Maciej Szpunar in Tobias Mc Fadden v Sony Music Entertainment Germany GmbH, C-484/14, EU:C:2016:689.

${ }^{119}$ Opinion of Advocate General Maciej Szpunar in Tobias Mc Fadden v Sony Music Entertainment Germany GmbH, cit, [77].

${ }^{120}$ Opinion of Advocate General Maciej Szpunar in Tobias Mc Fadden v Sony Music Entertainment Germany GmbH, cit, [78]-[79].

${ }^{121}$ Opinion of Advocate General Maciej Szpunar in Tobias Mc Fadden v Sony Music Entertainment Germany GmbH, cit, [80] (emphasis added).
} 
between costs arisen before an injunction is granted and costs arisen after an injunction is granted, eg costs of implementation. ${ }^{122}$

The CJEU decision in Mc Fadden is more nuanced and targeted on this point than the AG Opinion, although it appears to depart substantially from it. Holding that the safe harbour protection does not preclude one from seeking an injunction against an intermediary whose services are used to infringe his IP rights ${ }^{123}$, the CJEU stated that the relevant rightholder can seek reimbursement from the intermediary at which the relevant injunction is addressed "of the costs of giving formal notice and court costs". ${ }^{124}$ Arguably this part of the Mc Fadden judgment closes the door to the idea that intermediaries should not bear any costs, and also raises the question whether rightholders should even bear the application costs of an injunction. In this sense, the CJEU decision may be at odds with relevant EU law provisions and earlier CJEU case law from which UK judges had drawn authority to hold that the application costs should be borne by rightholders.

\section{The policy debate}

In mid-2015 the EU Commission launched its DSMS, in which it outlined its plans to achieve a connected EU digital single market. ${ }^{125}$ Among other things the Commission announced that, while the rationale underlying the safe harbour regime in the E-commerce Directive remains valid today, online enforcement of IP rights should be improved also on consideration that the current system (especially notice-and-takedown) is at times slow and ineffective, and differences in national practice can impede enforcement. ${ }^{126}$ With particular regard to copyright, the Commission noted that:

"An effective and balanced civil enforcement system against commercial scale infringements ... is central to investment in innovation and job creation. In addition the rules applicable to activities of

\footnotetext{
${ }^{122}$ Cf contra M Husovec, 'Holey cap! CJEU drills (yet) another hole in the E-commerce Directive's safe harbors' (2016; forthcoming in JIPLP), available at https://papers.ssrn.com/sol3/Papers.cfm?abstract_id=2843816, pp 5-6.

${ }^{123}$ Mc Fadden, [76].

${ }^{124}$ Mc Fadden, [79].

${ }^{125}$ European Commission, Communication from the Commission to the European Parliament, the Council, the European Economic and Social Committee and the Committee of the Regions - A Digital Single Market Strategy for Europe, cit, p 2.

${ }^{126}$ European Commission, Communication from the Commission to the European Parliament, the Council, the European Economic and Social Committee and the Committee of the Regions - A Digital Single Market Strategy for Europe, cit, p 12.
} 
online intermediaries in relation to copyright protected works require clarification, given in particular the growing involvement of these intermediaries in content distribution."127

As such, the EU Commission announced that over the coming period it would issue proposals clarifying the rules on the activities of intermediaries in relation to copyright-protected content and, in 2016, proposals to modernize the enforcement of IP rights, focusing on commercial-scale infringements (the 'follow the money' approach) as well as its cross-border applicability. ${ }^{128}$

Further to the release of the DSMS, the EU Commission launched a number of public consultations, including one on online platforms, cloud and data, liability of intermediaries, and the collaborative economy (ended on 26 January 2016), and one on the evaluation and modernization of the legal framework for the enforcement of IP rights (ended on 15 April 2016). From the responses to the former it appears that views are divided regarding the suitability of the current intermediary liability regime under the E-commerce Directive. ${ }^{129}$ From the responses to the latter, it appears that disparities in Member States' laws are seen as problematic and, with specific regard to intermediary injunctions, some respondents (notably rightholders, and the judiciary and legal profession) have called for a clarification of the scope of relevant injunctions. ${ }^{130}$

In September 2016 the EU Commission issued a number of proposals in the area of copyright, including a proposal for a directive on copyright in the Digital Single Market. ${ }^{131}$ Although not directly addressing issues facing copyright enforcement, the provision contained in Article 13 (so called 'value gap' proposal, to be read in conjunction with Recitals 38 and 39 in the preamble to that directive) is relevant because it appears to impose additional obligations on a particular type of hosting provider, ie providers that give access to 'large amounts of copyright protected works'. ${ }^{132}$ All this makes one wonder what the relationship between Article 13 of the proposed directive and relevant provisions in the E-commerce Directive (notably Articles 14

\footnotetext{
${ }^{127}$ European Commission, Communication from the Commission to the European Parliament, the Council, the European Economic and Social Committee and the Committee of the Regions - A Digital Single Market Strategy for Europe, cit, p 7.

${ }^{128}$ European Commission, Communication from the Commission to the European Parliament, the Council, the European Economic and Social Committee and the Committee of the Regions - A Digital Single Market Strategy for Europe, cit, p 8.

${ }^{129}$ European Commission, Public consultation on the regulatory environment for platforms, online intermediaries, data and cloud computing and the collaborative economy (26 January 2016), available at https://ec.europa.eu/digital-singlemarket/en/news/results-public-consultation-regulatory-environment-platforms-online-intermediaries-data-and.

${ }^{130}$ European Commission - Directorate-General for Internal Market, Industry, Entrepreneurship and SMEs, Public consultation on the evaluation and modernisation of the legal framework for the enforcement of intellectual property rights - Summary of responses, (2016), cit, pp 33-34.

${ }^{131}$ European Commission, Proposal for a directive of the European Parliament and of the Council on copyright in the Digital Single Market, cit.

${ }^{132}$ European Commission, Proposal for a directive of the European Parliament and of the Council on copyright in the Digital Single Market, cit, Recital 38.
} 
and 15) is, lacking an express mention of the latter directive in the body of the proposed new piece of EU legislation. ${ }^{133}$

Despite the timeframe indicated in the 2015 DSMS, a more thorough review of the enforcement framework is expected in the first half of 2017, including the release of proposals to review existing EU legislation.

\section{Looking into the (EU) future}

From the discussion of the UK scenario, three main threads emerge.

First, the availability of injunctions against intermediaries has proved a successful remedy in the hands of rightholders. Even more so, according to Arnold J a particular type of intermediary injunction, ie blocking injunctions, does not current have any alternatives that are more effective. In this sense, the relevance of two major developments is self-apparent: first, the CJEU confirming the compatibility of this measure with the EU legal order (UPC Telekabel) and, secondly, the Court of Appeal of England and Wales upholding the analysis of Arnold J that also trade mark owners can avail themselves of this tool.

Secondly, the UK experience demonstrates how - despite the EU harmonization efforts in the area of IP enforcement - there remain significant lacunae in the resulting framework (the issue of costs being an example), not to mention the fact that certain key provisions, eg the third sentence in Article 11 of the Enforcement Directive, have not been transposed fully or tout court into certain national IP regimes.

All this leads to a third, final point: should the EU merely reform the existing EU enforcement framework without pushing the boundaries of harmonization further, or should - instead - more harmonization be provided? In light of the responses to the consultation on the review of the enforcement framework, as well as dissenting views on key aspects like costs, it is submitted that this question should be addressed at the EU level, even before any specific proposals are tabled. This is particularly - albeit not only - so in a cross-border context. Although cross-border injunctions are currently said to be more frequent in respect to direct infringers rather than intermediaries, one of the principal obstacles that rightholders have flagged is the diverging substantive scope of injunctions in different Member States ${ }^{134}$, as well as costs of injunctions. ${ }^{135}$

\footnotetext{
${ }^{133}$ See S Stalla-Bourdillon and Others, A brief exegesis of the proposed Copyright Directive (2016; forthcoming in CSLR), available at https://ssrn.com/abstract=2875296, pp 6-7. In a similar sense, see also K Eisele - N Tack, European Parliamentary Research Service Briefing: Initial Appraisal of a European Commission Impact Assessment: Modernisation of EU copyright rules (December 2016), available at http://www.europarl.europa.eu/RegData/etudes/BRIE/2016/593799/EPRS_BRI(2016)593799_EN.pdf, p 6.

${ }^{134}$ European Commission - Directorate-General for Internal Market, Industry, Entrepreneurship and SMEs, Public consultation on the evaluation and modernisation of the legal framework for the enforcement of intellectual property rights - Summary of responses, (2016), cit, pp 33-34.
} 
Intermediaries have instead expressed the view that the implementation of injunctions impacts on their operations primarily in terms of additional costs, staff and technical infrastructure but might also result in adjusting the service offer. ${ }^{136}$

At the time of adopting the Enforcement Directive, EU legislature stressed how disparities between the systems of the Member States as regards the means of enforcing IP rights are prejudicial to the proper functioning of the internal market, make it impossible to ensure that IP rights enjoy an equivalent level of protection throughout the $\mathrm{EU}^{137}$, and also lead to a weakening of substantive IP law. ${ }^{138}$ Overall, if the rationale underlying the Enforcement Directive still holds valid today, then any reform discourse should start from the awareness of how, despite harmonizing efforts, the current legislative framework has significant shortcomings that courts - whether at the EU or UK levels - have been called to overcome. Lack of legislative guidance at the EU level on certain key issues, together with different national implementations of EU law provisions, makes one wonder whether what is needed is just a review of the existing enforcement framework, or rather a deeper and broader harmonizing action on the side of EU legislature. In light of previous EU harmonization efforts, but also difficulties lamented by relevant stakeholders, the latter appears to be the preferable answer.

\footnotetext{
${ }^{135}$ European Commission - Directorate-General for Internal Market, Industry, Entrepreneurship and SMEs, Public consultation on the evaluation and modernisation of the legal framework for the enforcement of intellectual property rights - Summary of responses, (2016), cit, p 33.

${ }^{136}$ European Commission - Directorate-General for Internal Market, Industry, Entrepreneurship and SMEs, Public consultation on the evaluation and modernisation of the legal framework for the enforcement of intellectual property rights - Summary of responses, (2016), cit, p 34.

${ }^{137}$ Enforcement Directive, Recital 8.

${ }^{138}$ Enforcement Directive, Recital 9.
} 